Evaluasi: Jurnal manajemen Pendidikan Islam

ISSN (P): 2580-3387, ISSN (E): 2615-2886

DOI : http://doi.org/10.32478/evaluasi.v5i2.764

Article Type : Original Research Article

\title{
PENGALAMAN PROSES PEMBELAJARAN JARAK JAUH DI PERGURUAN KEAGAMAAN ISLAM NEGERI: DAMPAK PANDEMI COVID-19
}

\author{
Slamet \\ Universitas Islam Negeri Maulana Malik Ibrahim Malang, Indonesia
}

Corresponding author: slametphd@manajemen.uin-malang.ac.id

Submission Track:

Submisson $\quad: 22-08-2021$

Accept Submission : 07-09-2021

Avaliable Online : :11-09-2021

Copyright @ 2021 Author

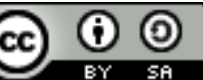

This work is licensed under a Creative Commons Attribution-ShareAlike 4.0

\begin{abstract}
The Covid-19 pandemic has wholly changed all aspects of life, including the learning system in higher education. So that the learning process must be carried out with a total distance education model, in its implementation, it is not accompanied by good planning. The main purpose of this study is to describe and examine the differences in the experiences of lecturers and students in carrying out the learning process with the distance education model as the impact of the Covid-19 Pandemic. This research was conducted using a descriptive quantitative approach and a different test. The research instrument is a questionnaire designed based on distance education theory. The measurement scale uses a Likert scale (1=strongly disagree to $5=$ strongly agree). Data were collected through surveys to lecturers and students. Due to the Covid19 pandemic, the questionnaire was designed in a Google Form and distributed through the WhatsApp Group of colleagues at several Islamic Universities in Indonesia. The number of respondents collected was $N=527$ ( $n=123$ lecturers and $n=404$ students). Before data analysis, data were edited, and the result was that all data were declared valid. Data analysis used the Categorization Index and a different test with the Independent-Samples Kolmogorov-Smirnov Test approach. The results of the descriptive research show that the learning process using the distance education model, from the experience of the lecturers, is stated to be less effective and even tends to be ineffective. Student experience
\end{abstract}


also shows the same thing, which is less effective, and the small number of many students say it is effective. The difference in experience in the learning process with the distance education model between lecturers and students is different. This difference is caused by the habit between lecturers and students using information technology devices as a medium in distance education that is not the same.

Keywords: Experience, Learning Process, Distance Education, Difference, Covid19 Pandemic.

\begin{abstract}
Abstrak
Pandemi Covid-19 telah merubah semua tatanan kehidupan, termasuk sistem pembelajaran di perguruan tinggi secara totali dan terjadi secara mendadak. Sehingga proses pembelajaran harus dilakukan dengan model pendidikan jarak jauh secara penuh. Dalam pelaksanaannya tidak disertai dengan perencanaan secara baik. Tujuan utama penelitian ini yaitu untuk mendeskripsikan dan menguji perbedaan pengalaman dosen dan mahasiswa dalam melakukan proses pembelajaran dengan model pendidikan jarak jauh sebagai dampak Pandemi Covid-19. Penelitian ini dilakukan menggunakan pendekatan kuantitatif deskriptif dan uji beda. Instrumen penelitian berupa kuesioner yang didesain berdasarkan teori pendidikan jarak jauh. Skala pengukuran menggunakan skala likert (1=sangat tidak setuju sd 5=sangat setuju). Data dikumpulkan melalui survei kepada dosen dan mahasiswa. Oleh karena masa Pandemi Covid-19, kuesioner didesain dalam bentuk Google Form dan didistribusikan melalui WhastApp Group kolega di beberapa Perguruan Tinggi Keagamaan Islam di Indonesia. Jumlah responden terkumpul sebanyak $N=527$ ( $n=123$ dosen dan $n=404$ mahasiswa). Data sebelum dilakukan analisis, terlebih dahulu dilakukan observasi data dan hasilnya semua data dinyatakan valid. Analisis data menggunakan Indeks Kategorisasi dan uji beda dengan pendekatan Independent-Samples Kolmogorov-Smirnov Test. Hasil penelitian secara deskriptif meunjukkan bahwa proses pembelajaran dengan model pendidikan jarak jauh, dari pengalaman dosen dinyatakan kurang efektif dan bahkan cenderung tidak efektif. Pengalaman mahasiswa juga menunjukkan hal yang sama yaitu kurang efektif, tetapi sebagian kecil mahasiswa menyatakan efektif. Perbedaan pengalaman dalam proses pembelajaran dengan model pendidikan jarak jauh, antara dosen dan mahasiswa berbeda. Perbedaan ini disebabkan oleh kebiasaan antara dosen dan mahasiswa menggunakan perangkat teknologi informasi sebagai media dalam pendidikan jarak jauh yang ytidak sama.
\end{abstract}

Keywords: Pengalaman, Proses Pembelajaran, Pendidikan Jarak Jauh, Perbedaan, Pandemi Covid-19.

\title{
A. PENDAHULUAN
}

\section{Pengantar}

Organisasi Kesehatan Dunia (WHO) telah menetapkan penyakit Coronavirus Disease 2019 (Covid-19) sebagai Pandemi pada 11 Maret 2020 (Covid19.go.id, 2020). Penetapan ini membuktikan bahwa Pandemi Covid-19 telah melanda dunia termasuk 
Indonesia. Pandemi Covid-19 masuk Indonesia terkonfirmasi pada tanggal 2 Maret 2020 dan dinyatakan sebagai Bencana Non-Alam (Pranita, 2020). Dampak daripada Pandemi Covid-19 di Indonesia yaitu terbitnya Keputusan Presiden Nomor 12 Tahun 2020 tentang Penetapan Bencanan Non-Alam. Rentetan keputusan tersebut dalam institusi pendidikan terbit Surat Edaran Menteri Pendidikan dan Kebudayaan Nomor 36962/MPK.A/HK/2020 tentang Pembelajaran secara Daring dan Bekerja dari Rumah dalam rangka Pencegahan Penyebaran Covid-19, Surat Edaran Menteri Pendidikan dan Kebudayaan Nomor 4 Tahun 2020 tentang Pelaksanaan Kebijakan Pendidikan dalam Masa Darurat Penyebaran Covid-19, Surat Edaran Direktur Jenderal Pendidikan Islam Nomor 657/03/2020 tentang Upaya Pencegahan Penyebaran Covid-19 di Lingkungan Perguruan Tinggi Keagamaan Islam. Sampai bulan April 2020, dilaporkan 95\% perguruan tinggi di Indonesia telah melaksanakan distance education (Widyanuratikah, 2020).

Dampak Pandemi Covid-19 dan menindaklanjuti kebijakan pemerintah tersebut, membuat sistem pembelajaran harus berubah secara radikal, termasuk system pembelajaran di Perguruan Tinggi Keagamaan Islam Negeri (PTKIN). Sebelum Pandemi Covid-19, belum pernah ada kebijakan pembelajaran dengan model pendidikan jarak jauh (distance education). Namun, akibat dampat Pandemi Covid-19, seluruh sistem pembelajaran dilakukan dengan model tatap muka penuh (pure faceto-face). Perubahan radikal ini, memiliki pengalaman tersendiri bagi dosen dan mahasiswa. Karena pembelajaran dengan model Pendidikan jarak jauh belum pernah dilakukan sebelumnya.

Tujuan utama penelitian ini adalah untuk mendeskripsikan dan menguji perbedaan pengalaman dosen dan mahasiswa dalam melaksanakan pendidikan jarak jauh sebagai dampak dari Pandemi Covid-19. Tujuan penelitian ini penting bagi penyelenggara pendidikan tinggi sebagai dasar kebijakan pelaksanaan pendidikan jauh. Peneliti berkeyakinan bahwa pendidikan jarak jauh yang berlangsung sekarang ini akan terus digunakan dengan berbagai pendekatannya. Dasar argumen tujuan ini yaitu pelaksanaan pendidikan jarak jauh merupakan kebijakan yang sangat mendadak akibat Pandemi Covid-19. Oleh karena kebijakan mendadak, sudah barang tentu pelaksanaan pendidikan jarak jauh di PTKIN tidak dilakukan melalui manajemen pendidikan jarak jauh yang dilakukan secara sistematis dan secara baik. Pendidikan jarak jauh yang dilakukan secara mendadak tersebut, sehingga dosen sebagai aktor dalam pendidikan tinggi, mencari cara, teknik, dan pendekatan yang sangat beragam. Begitu juga mahasiswa, meskipun mereka tergolong kaum millennials, tetapi ketika mengikuti proses pembelajaran dengan model pendidikan jarak jauh, mereka belum tentu siap. Oleh sebab itu, menggali pengalaman dosen dan mahasiswa menjadi penting. Khususnya yang berkaitan dengan pembelajaran, bimbingan karya ilmiah, dan pelaksanaan ujian-ujian serta tingkat e-literacy. Oleh sebab itu, hal ini menarik untuk dianalisis, sebelum Pandemi Covid-19, kebijakan proses pembelajaran dilaksanakan dengan model tatap muka murni. 


\section{Isu-isu Pendidikan Jarak Jauh}

Banyak perguruan tinggi yang telah menerapkan model pendidikan jarak jauh, masih dilaporkan banyak menghadapi hambatan dan tantangan. Misalnya, hambatan tentang rendahnya motivasi dan kemampuan belajar, lemahnya akses teknologi, hambatan keuangan, dan waktu belajar individu peserta didik (Musingafi et al., 2015; Rezaei, 2009); memerlukan perubahan gaya belajar, ketrampilan teknis, partisipasi belajar, dan ekspektasi belajar (Bower, 2001; Kebritchi et al., 2017); memerlukan adaptasi lingkungan dan waktu belajar (Wang, 2015); terjadinya perubahan peran, transisi model pembelajaran, dituntut melakukan perubahan gaya dan proses pembelajaran oleh tenaga pendidik (Kebritchi et al., 2017); tenaga pendidik tidak dapat mengendalikan etika, sikap, perilaku, kemajuan hasil belajar, dan tidak terjadi umpan balik pembelajaran (Wang, 2015); terjadinya peran tenaga pendidik, hilangnya proses pendidikan, dan memerlukan kesiapan bahan pembelajaran secara baik (Fojtík, 2018). Beberapa hambatan dan tantangan lain yang dihadapi secara institusional, misalnya terjadinya perubahan pelayanan dan sistem administasi pembelajaran (Bower, 2001; Musingafi et al., 2015); memerlukan kebijakan baru, harus menyediakan dukungan teknologi dan infrastruktur dengan baik, meningkatkan tingkat profesionalitas tenaga pendidik, dan harus memberikan pelatihan kepada tenaga pendidik dan peserta didik (Kebritchi et al., 2017). Dengan demikian, sesungguhnya penerapan model pembelajaran jauh yang dilaksanakan oleh beberapa perguruan tinggi tingkat dunia masih menyisahkan masalah.

Secara teoritik, konsep pendidikan jarak telah dikenal di Eropa sejak tahun 1800-an dengan istilah pendidikan korespondensi. Dalam perkembangannya, pendidikan jarak mempunyai beberapa sinonim yang sama, diantaranya pendidikan korepondensi, pendidikan lewat media radio, pendidikan melalui media TV, penggunaan telekonferen, komputer dan multimedia, sampai pembelajaran online (Jung, 2019). Open teaching, open learning, non-tradisional learning, distance teaching, correspondence education, distance learning, home study, independent study, external learning/study, flexible learning/education, life-long education/learning, experiential learning, directed private study, contract learning, self acces learning, dan individualized learning (Bozkurt, 2019). Online learning, flipped learning, flexible learning, blended learning, hybrid learning, open learning, dan distance learning (Bates, 2015). Dan, e-learning, distributed learning, mixed node, blended dan hybrid courses (Bates, 2005).

Distance education bukanlah konsep baru dalam bidang pendidikan. Buktinya adalah telah banyak diperbincangkan dan dikaji oleh banyak pakar berbagai perspektif. Studi dari aspek perspektif tantangan distance education (Bower, 2001; Fojtík, 2018; Guri-Rosenblit, 2013; Huang et al., 2020; Kebritchi et al., 2017; Mapuva, 2009; Mathew \& Iloanya, 2016; Moodley, 2002; Musingafi et al., 2015; Ramírez Montoya, 2013; Rezaei, 2009; Wang, 2015). Dari perspektif keunggulan dan kekurangan distance education (Arkorful \& Abaidoo, 2015; Dumford \& Miller, 2018; O’Donoghue et al., 2004; Oliveira et al., 2018; Pardanjac et al., 2009; Pishvanova et al., 
n.d.; Tibi \& Tibi, 2009; Vlasenko \& Bozhok, 2013). Perspektif persepsi dan kepuasan peserta didik (Kutluk \& Gulmez, 2012; Markova et al., 2017; Martens et al., 2007; Messo, 2014; Nwankwo, 2015; Tao \& Rosa Yeh, 2008). Studi dari aspek perspektif implementasi distance education (Alsoliman, 2015; Dirani \& Won Yoon, 2000; Nsamba, 2016; Yaumi, 2007). Terakhir, studi dalam perspektif distance education sebagai katalis perubahan (Christo-Baker, 2004). Dengan demikian, kajian-kajian tentang distance education tingkat dunia telah banyak diperbincangkan oleh banyak pakar. Sehingga, dapat dikatakan bahwa konsep distance education bukan merupakan konsep dan model pendidikan yang baru bagi mereka.

\section{Konsep dan Teori Dasar Pendidikan Jarak Jauh}

Banyak ditemui dalam berbagai literatur, istilah dan definisi pendidikan jarak jauh merujuk pada definisi pembelajaran jarak jauh. Kedua definisi tersebut seringkali digunakan saling bergantian (Bates, 2015; Fojtík, 2018; Heydenrych \& Prinsloo, 2010; Vlasenko \& Bozhok, 2013; Yaumi, 2007). Pembelajaran jarak jauh merupakan pengembangan dari pendidikan jarak jauh (Bozkurt, 2019). Pembelajaran jarak jauh dan pendidikan jarak jauh adalah sama (Vlasenko \& Bozhok, 2013). Hal ini menekankan bahwa pembelajaran merupakan bagian dari pendidikan. Pendidikan jarak jauh merupakan pembelajaran instruksional yang diformalkan, dimana waktu dan geografis membatasi kontak secara langsung (King et al., 2001). Pembelajaran yang dilakukan secara terpisah dengan media elektronik atau cetak (Schlosser \& Simonson, 2009; Simonson et al., 2006; UNESCO, 2002). Sistem pembelajaran yang direncanakan pada tempat berbeda yang dimediasi oleh teknologi dan diorganisir oleh penyelenggara pendidikan (Moore \& Kearsley, 2011; Newby et al., 2000). Secara konseptual, pendidikan jarak jauh yaitu adanya komunikasi yang tidak saling berdekatan yang konsisten antara penyelenggara pendidikan dengan peserta didiknya.

Ada dua jenis komunikasi dalam pendidikan jarak jauh yaitu one-way traffic dan two-way traffic. One-way traffic merupakan pembelajaran satu arah, yang mana materi pembelajaran dikirim kepada peserta didik yang telah rancang sebelumnya dan peserta didik berinteraksi berdasarkan teks pembelajaran. Sedangkan, two-traffic adalah komunikasi dua arah yang melibatkan peserta didik dengan penyelenggara pendidikan, tetapi komunikasi ini tidak berdekatan dan dimediasi oleh media tertentu. Dengan demikian, inti pendidikan jarak jauh adalah pelaksanaan pembelajaran yang dilaksanakan pada lokasi dan waktu yang berbeda antara tenaga pendidik dengan peserta didik (Moore \& Kearsley, 2011). Pendidikan jarak jauh yang didasarkan desain kebijakan oleh institusi, maka tujuan pendidikan jarak jauh tersebut adalah untuk memberikan dan membentuk kemandirian peserta didik dalam belajar (Keegan, 1986).

Oleh karena pendidikan jarak tidak dalam satu ruang atau lokasi yang sama, maka perlu ada pendekatan dalam pendidikan jarak jauh agar tujuan pendidikan dapat tercapai. Cheng et al. (2017) menyatakan pentingnya landasan filosofis dan landasan psikologis sebagai kerangka teoritik dalam pelaksanaan pendidikan jarak 
jauh. Keegan (1986), menyatakan ada tiga teori dasar yang harus diperhatikan dalam pendidikan jarak jauh, diantaranya teori kemandirian dan otonomi, teori pengajaran industrialisasi dengan teori interaksi dan komunikasi. Teori kemandirian dan otonomi adalah memberikan kebebasan kepada peserta didik tentang cara belajar yang tidak harus mendatangi ruang belajar bersama tenaga pendidik. Justifikasi ini adalah peserta didik dalam proses belajar dengan cara mempelajari pokok pelajaran melalui buku dan mendengarkan pelajaran melalui media elektronik (audio-visual) yang tidak terikat dengan orang lain. Sehingga, peserta didik mempunyai hak otonom dalam belajar. Tujuan belajar mandiri agar peserta didik mempunyai tanggungjawab dalam menentukan tujuan, proses belajar, dan capaian dari hasil pembelajaran (Keegan, 1983).

Teori pengajaran industrialisasi menyatakan bahwa pembelajaran dalam teori industrialisasi menganut faham mekanisasi dan otomatisasi. Adanya mekanisasi, jalur perakitan, produksi masal, formalisasi, standarisasi, sentralisasi, and lainnya merupakan bukti faham mekanisasi dan otomatisasi pada pembelajaran (Peters, 2007). Teori interaksi dan komunikasi dalam pendidikan bermakna pendidikan harus terjadi proses interaksi dan komunikasi dua arah. Dalam model komunikasi interaksi, terjadinya proses melingkar komunikasi dua arah dan komunikasi tersebut dapat terjadi dengan baik, jika terjadi dalam sebuah interaksi (West \& Turner, 2008). Oleh sebab itu, Holmberg (1989) menyatakan bahwa pendidikan jarak jauh harus dikawal oleh teori interaksi dan komunikasi. la menegaskan bahwa teori tersebut nilai yang berkaitan dengan efektifitas pembelajaran yang berdampak pada perasaan saling memiliki dan kerjasama yang baik, tukar pemikiran, tukar pertanyaan, tukar jawaban, dan argumen. Asumsi teori ini yaitu manusia bertindakan atas dasar makna yang diberikan orang lain. Makna tercipta karena adanya interaksi antar manusia, dan makna dimodifikasi melalui interpretasi.

Merujuk Simonson \& Schlosser (1999), pendekatan teoritis yang tepat dalam pendidikan jarak jauh adalah konsep kesetaraan. la berpendapat bahwa pendidikan jarak jauh secara formal dan institusional merupakan aktivitas pendidikan antara tenaga pendidik dan peserta didik terpisah satu sama lain. Sistem telekomunikasi memungkinkan terjadinya komunikasi interaktif dua arah baik secara synchronous maupun asynchronous. Ada lima elemen kunci dalam teori kesetaraan yaitu kesetaraan, pengalaman pembelajaran, aplikasi yang tepat, peserta didik, dan outcome. Dalam teori kesetaraan, dijelaskan bahwa secara fundamental jarak dan lokasi peserta didik dalam lingkungan yang berbeda. Oleh sebab itu, tenaga pendidik bertanggungjawab dalam merancang pembelajaran atau menyediakan modul harus memberikan pengalaman yang sama antar peserta didik. Selanjutnya, Simonson berpendapat bahwa hal kedua terpenting adalah pengalaman belajar, termasuk apa yang diamati, dirasakan, didengar, atau dilakukan oleh peserta didik. Untuk memberikan pengalaman tersebut perlu dukungan aplikasi yang tepat dalam pelaksanaan pendidikan jarak jauh. Outcome dari pengalaman belajar yaitu terjadinya perubahan yang jelas dan terukur. 


\section{Pendekatan Pendidikan Jarak Jauh}

Secara konseptual, ada tiga pendekatan pembelajaran yaitu pure face-to-face teaching, blended learning, and pembelajaran secara online penuh (Bates, 2015). Secara definitif dijelaskan sebagai berikut:

a. Pure face-to-face. la merupakan learning mode yang berpusat pada tenaga pendidik dan dilaksanakan di ruang kelas (Ananga \& Biney, 2017; Novak, 1998; Trianto, 2007). la merupakan salah satu mode yang telah teruji dan telah menjadi mode pembelajaran di perguruan tinggi di seluruh dunia (Svinicki \& McKeachie, 2011).

b. Blended learning. la merupakan salah satu pendekatan dalam pendidikan yang mengkombinasikan pembelajaran secara online dengan metode pembelajaran face-to-face (Owusu-Boampong \& Holmberg, 2015; Watson, 2008). Dalam blended learning dikenal istilah mixed mode, hybrid and blended courses. Mixed mode lebih ditekan pada pengurangan waktu belajar di kelas dibandingkan belajar secara online. Sebaliknya, hybrid and blended learning lebih menekan waktu belajar secara online dibanding di kelas (Bates, 2015). Dikatakan blended learning jika proporsi 30-79\% bahan pembelajaran disampaikan secara online (Owusu-Boampong \& Holmberg, 2015).

c. Pembelajaran online secara penuh. la merupakan mode learning tidak dalam ruang kelas atau di kampus. la merupakan salah satu bentuk Pendidikan jarak jauh (Bates, 2015). Di katakan online, jika mahasiswa mempunyai akses ke komputer dan internet untuk melakukan pembelajaran/kursus secara totalitas (Bates, 2005).

Ditinjau dari aspek teknologi beberapa pendekatan dalam pendidikan jarak jauh, yaitu synchronous dan asynchronous (Ananga \& Biney, 2017; Hrastinski, 2008), synchronous, asynchronous dan hybrid learning (Perveen, 2016). Synchronous dan asynchronous lebih detail dijelaskan sebagai berikut:

a. Asynchronous. la merupakan media pembelajaran yang memungkinkan partisipan dalam mengakses informasi pada waktu dan tempat yang berbeda (Bates, 2015), dan tenaga Pendidikan dan mahasiswa tidak dapat online secara riel time dalam waktu yang sama (Hrastinski, 2008). Bahan pembelajaran dalam bentuk audio, video, handouts, article dan presentasi power point dapat di akses kapan saja dan dimana saja (Perveen, 2016), yang difasilitasi oleh media, seperti email, papan diskusi, DVDs, Youtube videos (Bates, 2015; Hrastinski, 2008), bisa juga melalui learning management system atau channels lainnya. Tantangan dalam asynchronous adalah perlu persiapan pembelajaran secara baik dan hati-hati, agar mahasiswa dapat termotivasi, berpartisipasi, percaya diri, mampu memecahkan masalah, kritis, dan menumbuhkan ketrampilan berfikir (Perveen, 2016).

b. Synchronous. la merupakan proses pembelajaran yang dilaksanakan secara bersama-sama melalui media elektronik (Perveen, 2016), diantaranya videoconference dan chat (Hrastinski, 2008). Suara dan/atau text chat 
memberikan peluang untuk melakukan interaksi antar mahasiswa dan/atau tenaga pendidik dan mahasiswa(Perveen, 2016). Pendekatan ini dapat dilaksanakan pada waktu yang sama tetapi tempat berbeda. Tetapi, tantangannya adalah tenaga pendidik dan mahasiswa perlu ketersediaan waktu dan bandwidth internet yang memadai (Perveen, 2016).

Dengan demikian, secara konseptual pendidikan jarak jauh dilaksanakan pada waktu dan/atau lokasi yang berbeda. Namun demikian, pendidikan jarak jauh harus memperhatikan beberapa aspek yang tidak boleh ditinggalkan, diantaranya adanya interaksi dan komunikasi, menekankan adanya faktor kesetaraan, adanya kemandiri dan otonomi dalam belajar peserta didik, dan efektif pembelajaran. Aspek-aspek tersebut bertujuan untuk mencapai tujuan pendidikan secara baik dan sekaligus memberikan pengalaman belajar bagi bagi tenaga pendidik maupun peserta didik.

\section{B. METODE PENELITIAN}

Penelitian ini menggunakan desain penelitian kuantitatif dengan pendekatan survei. Survei dilakukan di beberapa PTKIN di Indonesia pada bulan Juli sampai dengan Agustus 2020, tepatnya setelah pelaksanaan Semester Genap Tahun Akademik 2019/2020. Alasan penelitian ini dilakukan di PTKIN yaitu bahwa Universitas Islam Negeri (UIN), Institut Agama Islam Negeri (IAIN), dan Sekolah Tinggi Agama Islam (STAIN) diketahui belum pernah mengeluarkan kebijakan pendidikan jarak jauh sebelum Pandemi Covid-19. Sumber data penelitian ini termasuk sumber data primer yaitu dikumpulkan sendiri melalui survei. Responden yang berpartisi dalam survey ini yaitu sebanyak $(N)=527, n=123(23,24 \%)$ berstatus dosen dan $n=404 \quad(76,66 \%)$ berstatus mahasiswa. Kualifikasi pendidikan dosen bergelar doktor (41.50\%), masa kerja kurang dari 20 tahun (81.30\%), dan sebanyak 65.84\% mahasiswa duduk pada semester dua dan empat.

Instrumen dalam penelitian ini berupa kuesioner tertutup. Kuesioner didesain berdasarkan teori-teori pendidikan jarak jauh (King et al., 2001; Moore \& Kearsley, 2011; Newby et al., 2000; UNESCO, 2002), teori equivalence (Simonson \& Schlosserharles, 1999), teori kemandirian dalam belajar (Keegan, 1983), dan teori komunikasi dalam pendidikan jarak jauh (Holmberg, 1989). Skala pengukuran menggunakan skala likert ( $1=$ sangat tidak setuju sampai dengan $5=$ sangat setuju). Oleh karena masa Pandemi Covid-19, kuesioner didesain menggunakan Google Form dan distribusikan melalui Whatsapp Group di beberapa UIN, IAIN, dan STAIN di Indonesia.

Analisis data menggunakan analisis indeks kategorisasi (Azwar, 2012). Indeks kategori data dikelompokkan menjadi tiga, yaitu: 
Tabel 1: Indeks Kategorisasi

\begin{tabular}{cc}
\hline Rentang Skore & Kategorisasi \\
\hline $\mathrm{X} \leq \mu-1 \alpha$ & Tidak efektif/Rendah/Jenuh/Tidak setuju \\
\hline$\mu<\mathrm{X} \leq \mu+1 \alpha$ & Kurang efektif/Sedang/Kurang nyaman/Kurang setuju \\
\hline $\mathrm{X}>\mu+1 \alpha$ & Efektif/Tinggi/Nyaman/Setuju
\end{tabular}

Untuk mengetahui perbedaan pengalaman antara dosen dan mahasiswa dalam pembelajaran dengan model pendidikan jarak jauh, peneliti menggunakan uji beda dengan pendekatan Independent-Samples Kolmogorov-Smirnov Test dengan tingkat kesalahan $(\alpha)=5 \%$. Adapun keputusan hipotesis, jika Asymp.Sig. $(p) \leq 0.05$, bermakna ada perbedaan dan sebaliknya Asymp.Sig. $(p)<0.05$, bermakna tidak ada perbedaan.

\section{HASIL DAN PEMBAHASAN}

\section{Paparan Hasil Analisis Data Penelitian}

Berdasarkan tujuan penelitian, hasil penelitian dipaparkan menjadi empat bagian yaitu pengalaman perkuliahan, pengalaman bimbingan karya ilmiah, dan pengalaman pelaksanaan ujian-ujian, dan perbedaan pengalaman pembelajaran antara dosen dan mahasiswa dalam pembelajaran dengan model pendidikan jarak jauh.

\section{a. Pengalaman Proses Perkuliahann}

Proses perkuliahan merupakan interaksi dosen dengan mahasiswa yang didukung oleh sumber belajar dalam waktu tertentu yang dilaksanakan secara terpisah dengan media teknologi informasi dan jaringan internet. Tabel 2 memaparkan data tentang pengalaman dosen dan mahasiswa selama mengikuti proses pembelajaran yang dilaksanakan dengan model pendidikan jarak jauh.

Tabel 2: Kategorisasi Pengalaman Proses Perkuliahan

\begin{tabular}{llllc}
\hline \multirow{2}{*}{ No } & \multicolumn{1}{c}{ Aspek pengukuran } & Kategori, Std. & \multicolumn{2}{c}{ Pengalaman } \\
\cline { 4 - 5 } & & $\begin{array}{c}\text { Deviation, dan } \\
\text { variance, }\end{array}$ & Dosen & Mahasiswa \\
\hline 1. & Efektifitas penyampaian materi & Tidak efektif & 21.10 & 12.90 \\
& pembelajaran yang disampaikan oleh & Kurang efektif & 69.10 & 68.60 \\
& dosen secara online & Efektif & 9.80 & 18.60 \\
& & Std. Dev. $(s)$ & 0.55 & 0.56 \\
2. & Tingkat pemahamaman mahasiswa & Variance & 0.30 & 0.31 \\
& dalam menerima materi pembelajaran & Sedang & 0.80 & 12.90 \\
& yang disampaikan oleh dosen secara & Tinggi & 96.70 & 70.80 \\
& online. & Std. Dev. $(s)$ & 2.40 & 16.30 \\
& & Variance & 0.18 & 0.54 \\
3. & Tingkat partisipasi mahasiswa dalam & Rendah & 7.30 & 0.29 \\
& & & & 7.90
\end{tabular}




\begin{tabular}{|c|c|c|c|c|}
\hline \multirow[b]{2}{*}{ No } & \multirow[b]{2}{*}{ Aspek pengukuran } & \multirow{2}{*}{$\begin{array}{l}\text { Kategori, Std. } \\
\text { Deviation, dan } \\
\text { variance, }\end{array}$} & \multicolumn{2}{|c|}{ Pengalaman } \\
\hline & & & Dosen & Mahasiswa \\
\hline \multirow{9}{*}{4.} & \multirow{4}{*}{$\begin{array}{l}\text { mengikuti proses pembelajaran secara } \\
\text { online. }\end{array}$} & Sedang & 88.60 & 85.60 \\
\hline & & Tinggi & 4.10 & 26.50 \\
\hline & & Std. Dev. (s) & 0.34 & 0.56 \\
\hline & & Variance & 0.11 & 0.31 \\
\hline & \multirow{5}{*}{$\begin{array}{l}\text { Tingkat kejenuhan dosen / mahasiswa } \\
\text { dalam proses pembelajaran secara } \\
\text { online. }\end{array}$} & Jenuh & 25.20 & 29.00 \\
\hline & & $\begin{array}{l}\text { Kurang } \\
\text { nyaman }\end{array}$ & 69.90 & 67.30 \\
\hline & & Menyenangkan & 4.90 & 3.70 \\
\hline & & Std. Dev. (s) & 0.51 & 0.51 \\
\hline & & Variance & 0.26 & 0.26 \\
\hline \multirow[t]{5}{*}{5.} & \multirow{5}{*}{$\begin{array}{l}\text { Efektifitas pelaksanaan perkuliahan } \\
\text { secara online. }\end{array}$} & Tidak efektif & 3.30 & 12.60 \\
\hline & & Kurang efektif & 94.3 & 74.50 \\
\hline & & Efektif & 2.40 & 12.90 \\
\hline & & Std. Dev. (s) & 0.24 & 0.51 \\
\hline & & Variance & 0.06 & 0.26 \\
\hline \multirow[t]{5}{*}{6.} & \multirow{5}{*}{$\begin{array}{l}\text { Efektifitas pengumpulan dan koreksi } \\
\text { tugas-tugas mahasiswa secara online. }\end{array}$} & Tidak efektif & 86.20 & 8.40 \\
\hline & & Kurang efektif & 13.80 & 54.70 \\
\hline & & Efektif & 0.00 & 36.90 \\
\hline & & Std. Dev. (a) & 0.35 & 0.61 \\
\hline & & Variance & 0.12 & 0.37 \\
\hline
\end{tabular}

Dalam Tabel 2, memperlihatkan pengalaman proses perkuliahan dengan model pendidikan jarak jauh pada kategori kedua, yaitu kurang efektif/sedang/kurang nyaman/kurang setuju atas pernyataan yang diajukan kepada responden. Kecuali pernyataan keenam, pengumpulan dan koreksi tugas-tugas secara online, dosen menyatakan tidak efektif, sementara mahasiswa menyatakan kurang efektif dan sebagian lain menyatakan efektif. Skore Std.Dev. dan varian masing-masing pernyataan relatif kecil yaitu mendekati skore 0 (nol). Ini bermakna bahwa masingmasing dosen dan mahasiswa sebagai responden memiliki pengalaman yang relatif sama.

\section{b. Pengalaman Proses Bimbingan Karya IImiah}

Salah satu proses pembelajaran adalah aktivitas bimbingan karya ilmiah. Tabel 3 mendeskripsikan pengalaman proses bimbingan karya ilmiah antara dosen dengan mahasiswa. 
Tabel 3: Kategorisasi Pengalaman Proses Bimbingan Karya Ilmiah

\begin{tabular}{|c|c|c|c|c|}
\hline \multirow[b]{2}{*}{ No } & \multirow[b]{2}{*}{ Aspek pengukuran } & \multirow{2}{*}{$\begin{array}{l}\text { Kategori, Std. } \\
\text { Deviation, dan } \\
\text { variance, }\end{array}$} & \multicolumn{2}{|c|}{ Pengalaman } \\
\hline & & & Dosen & Mahasiswa \\
\hline \multirow[t]{5}{*}{1.} & \multirow{5}{*}{$\begin{array}{l}\text { Pelaksanaan bimbingan karya ilmiah } \\
\text { mahasiswa secara online }\end{array}$} & Tidak setuju & 29.30 & 22.00 \\
\hline & & Kurang setuju & 63.40 & 70.50 \\
\hline & & Setuju & 7.30 & 7.40 \\
\hline & & Std. Dev. (s) & 0.57 & 0.52 \\
\hline & & Variance & 0.32 & 0.72 \\
\hline \multirow[t]{5}{*}{2.} & \multirow{5}{*}{$\begin{array}{l}\text { Tingkat pemahamaman mahasiswa } \\
\text { terhadap umpan balik (saran dan } \\
\text { arahan) dari dosen dalam bimbingan } \\
\text { secara online }\end{array}$} & Rendah & 3.30 & 16.30 \\
\hline & & Sedang & 92.70 & 65.60 \\
\hline & & Tinggi & 4.10 & 18.10 \\
\hline & & Std. Dev. (s) & 0.27 & 0.59 \\
\hline & & Variance & 0.07 & 0.34 \\
\hline \multirow[t]{5}{*}{3.} & \multirow{5}{*}{$\begin{array}{l}\text { Efektifitas bimbingan karya ilmiah } \\
\text { secara online }\end{array}$} & Tidak efektif & 5.70 & 19.10 \\
\hline & & Kurang Efektif & 89.40 & 68.80 \\
\hline & & Efektif & 4.90 & 12.10 \\
\hline & & Std. Dev. (s) & 0.33 & 0.56 \\
\hline & & Variance & 0.11 & 0.31 \\
\hline
\end{tabular}

Tabel 3 menunjukkan ada perbendaan pengalaman dalam proses bimbingan karya ilmiah. Proses bimbingan karya ilmiah kepada mahasiswa dengan model pendidikan jarak jauh, dosen mengklaim masuk kategori yaitu kurang efektif, mahasiswas mengklaim bahwa proses bimbingan karya ilmiah dengan model Pendidikan jarak jauh kurang efektif dan sebagian kecil tergolong kategori tidak efektif dan efektif. Skore standar deviasi dan varian sangat bagus karena memiliki skore yang sangat kecil atau mendekati skore 0 (nol). Hal ini bermakna bahwa pengalaman para dosen dan mahasiswa sebagai responden memberikan respon pengalamannya yang homogen.

\section{c. Pengalaman Pelaksanaan Ujian-Ujian}

Dalam pendidikan formal, salah satu tugas mahasiswa adalah mengikuti ujian untuk mengukur capaian hasil pembelajaran oleh seorang dosen. Tabel 4 dimaksudkan untuk menyajikan hasil analisis data tentang pengalaman pelaksanaan ujian baik oleh dosen maupun mahasiswa. 
Tabel 4: Kategorisasi Pengalaman Pelaksanaan Ujian

\begin{tabular}{|c|c|c|c|c|}
\hline \multirow[b]{2}{*}{ No } & \multirow[b]{2}{*}{ Aspek pengukuran } & \multirow{2}{*}{$\begin{array}{l}\text { Kategori, Std. } \\
\text { Deviation, dan } \\
\text { variance, }\end{array}$} & \multicolumn{2}{|c|}{ Pengalaman } \\
\hline & & & Dosen & Mahasiswa \\
\hline \multirow[t]{5}{*}{1.} & \multirow[t]{5}{*}{ Pelaksanaan ujian secara online } & Tidak setuju & 20.30 & 6.90 \\
\hline & & Kurang setuju & 72.40 & 71.30 \\
\hline & & Setuju & 7.30 & 21.80 \\
\hline & & Std. Dev. (s) & 0.51 & 0.52 \\
\hline & & Variance & 0.26 & 0.27 \\
\hline \multirow[t]{5}{*}{2.} & \multirow{5}{*}{$\begin{array}{l}\text { Tingkat interaksi dan pemahamaman } \\
\text { antara dosen dan mahasiswa selama } \\
\text { proses ujian secara online }\end{array}$} & Rendah & 0.80 & 5.70 \\
\hline & & Sedang & 91.10 & 60.40 \\
\hline & & Tinggi & 8.10 & 33.90 \\
\hline & & Std. Dev. (s) & 0.29 & 0.56 \\
\hline & & Variance & 0.08 & 0.32 \\
\hline \multirow[t]{5}{*}{3.} & \multirow{5}{*}{$\begin{array}{l}\text { Efektifitas pelaksanaan ujian secara } \\
\text { online }\end{array}$} & Tidak efektif & 2.40 & 7.40 \\
\hline & & Kurang Efektif & 92.70 & 65.60 \\
\hline & & Efektif & 4.90 & 27.00 \\
\hline & & Std. Dev. (s) & 0.27 & 0.55 \\
\hline & & Variance & 0.07 & 0.31 \\
\hline
\end{tabular}

Merujuk Tabel 4, memperlihatkan pengalaman pelaksanaan ujian-ujian untuk mengukur capaian proses pembelajaran yang dilakukan oleh seorang dosen kepada mahasiswa. Dosen memiliki pengalaman bahwa pelaksanaan ujian dengan model pendidikan jarak jauh, berdasarkan uji statistic masuk dalam kategori kedua yaitu kurang efektif. Sementara, pengalaman pihak mahasiswa memiliki pengalaman mengikuti ujian yang diselenggarakan oleh dosen sebagian tergolong kategori kedua dan sebagian lain kategori ketiga. Jika, dilihat tingkat keseragaman pengalaman baik dosen dan mahasiswa sangat homogen. Hal ini tunjukkan skore standar deviasi dan varian yang relative kecil.

Dengan demikian, temuan penelitian secara statistik proses pembelajaran dengan model pendidikan jarak jauh yang diukur dari proses perkuliahan, proses bimbingan karya ilmiah, dan pelaksanaan ujian dapat dikatakan kurang efektif.

\section{d. Analisis Perbedaan Pengalaman Proses Pembelajaran dengan Model Pendidikan Jarak Jauh}

Untuk mengetahui perbedaan pengalaman proses pembelajaran dengan model pendidikan jarak jauh, diukur dari empat aspek yaitu proses perkuliahan secara online penuh, proses bimbingan karya ilmiah online, pelaksanaan ujian secara online, dan tingkat e-literacy dosen dan mahasiswa. Hasil analisis disajikan dalam Tabel 5. 
Tabel 5: Hasil Analisis Uji Beda

\begin{tabular}{llcccc}
\hline No & \multicolumn{1}{c}{ Uji Perbedaan } & $\begin{array}{c}\text { Mean } \\
(\mu)\end{array}$ & $\begin{array}{c}\text { Std. } \\
\text { Deviation } \\
(\mathrm{a})\end{array}$ & $\begin{array}{c}\text { Asymp. } \\
\text { Sig. }(p)\end{array}$ & Keputusan \\
\hline 1. $\begin{array}{l}\text { Pengalaman proses } \\
\text { perkuliahan secara online } \\
\text { penuh }\end{array}$ & 17.25 & 4.23 & 0.000 & Ada perbedaan \\
$\begin{array}{l}\text { Pengalaman proses } \\
\text { bimbingan karya ilmiah }\end{array}$ & 8.08 & 2.68 & 0.000 & Ada perbedaan \\
$\begin{array}{l}\text { secara online } \\
\text { 4. Pengalaman pelaksanaan }\end{array}$ & 9.34 & 2.23 & 0.000 & Ada perbedaan \\
$\begin{array}{l}\text { ujian-ujian secara online } \\
\text { Tingkat e-literacy }\end{array}$ & 18.03 & 8.50 & 0.000 & Ada perbedaan \\
\hline
\end{tabular}

\section{Pembahasan Temuan Hasil Penelitian}

Temuan utama hasil penelitian ini memperlihatkan bahwa proses pembelajaran dengan model pendidikan jarak jauh - online secara penuh - yang dilakukan secara mendadak memberikan pengalaman kepada dosen dan mahasiswa yang kurang baik atau kurang menyenangkan dan secara subtantif kurang efektif. Bahkan condong ke kategori pertama yaitu tidak setuju proses pembelajaran dengan model pendidikan jarak jauh secara penuh. Hanya sebagian kecil mahasiswa saja yang menyatakan efektif. Proses pembelajaran dengan model pendidikan jarak jauh antara dosen dan mahasiswa memiliki pengalaman yang berbeda. E-literacy antara dosen dan mahasiswa juga berbeda. Dengan demikian, proses pembelajaran dengan model pendidikan jarak jauh yang dilakukan secara mendadak dan tidak ada perencanaan yang baik, menghasilkan proses pembelajaran yang kurang efektif dan bahkan tidak efektif.

Temuan ini memperkuat dan menambah isu-isu yang telah ditemukan oleh penelitian sebelumnya yang mengindikasikan bahwa proses pembelajaran dengan model pendidikan jarak jauh kurang efektif. Misalnya, Kebritchi et al. (2017) menemukan bahwa pendidikan jarak jauh menuntut adanya perubahan peran, terjadi transisi model pembelajaran, dituntut adanya perubahan gaya dan proses pembelajaran oleh tenaga pendidik. Wang (2015), menemukan bahwa dalam pendidikan jarak jauh, tenaga pendidik tidak dapat mengendalikan etika, sikap, perilaku, kemajuan hasil belajar, dan tidak terjadi umpan balik dalam proses pembelajaran. Fojtík (2018) juga berpendapat bahwa pendidikan jarak kurang efektif karena terjadinya perubahan peran tenaga pendidik, hilangnya proses pendidikan, dan memerlukan kesiapan bahan pembelajaran secara baik.

Masalah lain kurang efektifnya proses pembelajaran dengan model pendidikan jarak jauh, dapat disebabkan oleh rendahnya motivasi dan kemampuan belajar, lemahnya akses teknologi, hambatan keuangan, dan kurangnya waktu belajar (Musingafi et al., 2015; Rezaei, 2009). Kurang efektifnya pendidikan jarak jauh, disebabkan oleh buruknya dan belum meratanya sinyal jaringan internet, dan 
munculnya biaya tambahan (Mathew \& Iloanya, 2016; Musingafi et al., 2015; O'Donoghue et al., 2004; Pardanjac et al., 2009; Rezaei, 2009; Vlasenko \& Bozhok, 2013). Oleh sebab itu, proses pembelajaran dengan model pendidikan jarak jauh perlu dukungan kebijakan baru, dukungan teknologi dan infrastruktur yang baik dan dukungan profesionalitas tenaga pendidik sangat diperlukan (Kebritchi et al., 2017), dengan menggunakan pendekatan konsep kesetaraan Simonson \& Schlosser (1999).

Meskipun pendidikan jarak jauh kurang efektif berdasarkan temuan penelitian ini, namun sesungguhnya pendidikan jarak jauh memberikan peluang bagi peserta didik. Peluang-peluang tersebut dalam bahasa lain disebut dengan keunggulan dari model pendidikan jarak jauh. Misalnya dapat menjadikan peserta didik memiliki pola belajar mandiri dan berlatih disiplin, dapat memberi kesempatan kepada peserta didik yang tidak dapat belajar secara tatap muka yang harus datang ke kampus dalam ruang kelas - bagi peserta didik yang memiliki waktu dan kondisi fisik yang terbatas (difable) (Fojtík, 2018; Oliveira et al., 2018; Vlasenko \& Bozhok, 2013; Wang, 2015). Untuk menjembatani kelemahan dan peluang dalam pendidikan jarak jauh, Mapuva (2009) berpendapat bahwa manajemen perguruan tinggi harus melakukan readjust dan re-organize sistem pembelajaran. Sekaligus re-thinking, re-strategy, dan realignment dalam manajemen penyelenggaraan pendidikan tinggi.

Oleh sebab itu, Blended learning (Owusu-Boampong \& Holmberg, 2015; Watson, 2008) dan mixed mode (Bates, 2005), dapat dijadikan pendekatan dalam proses pembelajaran dengan model pendidikan jarak jauh. Media Synchronous dan Asynchronous juga dapat digunakan secara bersama secara proporsional. Oleh sebab itu, perguruan tinggi harus mampu menyediakan dan mengelola learning management system secara efektif dan memastikan ketersediaan bandwith internet bagi dosen dan mahasiswa memadai (Perveen, 2016). Pendekatan ini lebih relevan untuk dikembangkan pada sistem pembelajaran di perguruan tinggi dimasa depan, termasuk perguruan tinggi Islam di Indonesia. Kasus Pandemi Covid-19 yang telah melanda dunia, secara tidak langsung memberikan kesadaran dan pemahaman kepada perguruan tinggi, dosen, dan mahasiswa bahwa sistem pembelajaran tidak selamanya harus dilakukan secara face-to-face murni. Dengan demikian, manajemen perguruan tinggi harus merubah pola manajemennya, baik pada area pelayanan akademik maupun non-akademik dengan memperhatikan perkembangan teknologi informasi saat ini dan estimasi dimasa depan.

\section{KESIMPULAN}

Pendidikan jarak jauh yang dilaksanakan pada saat Pandemi Covid-19 menyadarkan kita semua dan menjadi momentum melakukan perubahan manajemen Pendidikan, khususnya di perguruan tinggi Islam. Dengan adanya Pandemi Covid-19, proses pembelajaran dengan model face-to-face secara penuh berubah secara total menjadi model pendidikan jarak jauh. Dalam pelaksanaannya, model pendidikan jarak jauh memperlihatkan kurang efektif. Secara konseptual, pendidikan jarak jauh memiliki kelebihan dan peluang dalam proses pembelajaran era digital. Tren proses pembelajaran pada saat dan pasca Pandemi Covid-19 model pendidikan jarak jauh 
tetap digunakan dengan beberapa penyesuaian. Penyesuaian proses pembelajaran di perguruan tinggi Islam di Indonesia yang lebih relevan yaitu blended learning. Blended learning merupakan pendekatan untuk menggabungkan antara proses pembelajaran dengan model face-to-face dan pendidikan jarak jauh dengan kombinasi $60 \%-70 \%$ face-to-face dan 30\%-40\% secara sistem online.

Hasil penelitian ini memiliki keterbatasan, karena dilakukan pada saat awal Pandemi Covid-19. Yang mana, proses pembelajaran dengan model pendidikan jarak jauh dilaksanakan secara mendadak. Secara individu, sebagian besar dosen dan mahasiswa belum terbiasa melaksanakan proses pembelajaran dengan model pendidikan jarak jauh. Secara institusional, sebelum Pandemi Covid-19, PTKIN juga belum mengeluarkan kebijakan dan sistem pembelajaran dengan model ini. Oleh sebab itu, direkomendasikan kepada peneliti yang lain untuk melakukan penelitian ulang pasca Pandemi Covid-19 bagi PTKIN yang masih menerapkan atau menetapkan pendidikan jarak jauh sebagai model dalam proses pembelajarannya.

\section{REFERENSI}

Alsoliman, B. (2015). A Strategic Approach To The Implementation Of Quality Distance Learning In Saudi Arabia: An Embedded Case Study [School of the Built Environment College of Science and Technology University of Salford]. http://usir.salford.ac.uk/id/eprint/37589/1/Final Version.pdf

Ananga, P., \& Biney, I. K. (2017). Comparing Face-To-Face And Online Teaching And Learning In Higher Education. MIER Journal of Educational Studies, Trends \& Practices, 7(2), 165-179. https://doi.org/10.52634/mier/2017/v7/i2/1415

Arkorful, V., \& Abaidoo, N. (2015). The role of e-learning, advantages and disadvantages of its adoption in higher education. International Journal of Instructional Technology and Distance Learning, 12(1), 29-42.

Azwar, S. (2012). Penyusunan Skala Psikologi (2nd ed.). Pustaka Pelajar.

Bates, A. W. (2005). Technology, e-learning and distance education (Second). Routledge.

Bates, A. W. (2015). Teaching in a digital age: Guidelines for designing teaching and learning for a digital age. Tony Bates Associates Ltd.

Bower, B. . (2001). Distance Education: Facing the Faculty Challenge. Online Journal of Distance Learning Administration, 4(2). https://www.learntechlib.org/p/92506/

Bozkurt, A. (2019). From distance education to open and distance learning: A holistic evaluation of history, definitions, and theories. In Handbook of Research on Learning in the Age of Transhumanism (pp. 252-273). Hershey, PA: IGI Global.

Cheng, L., Rushing, R., Xu, Z., \& Dogan, N. A. (2017). Theoretical Frameworks in Distance Education. In Distance Education: A Guide for Theory and Practice. https://www.aritzhaupt.com/distance_education/theoretical-frameworks/ 
Christo-Baker, E. A. (2004). Distance Education as a Catalyst for Change in Higher Education. Proceedings of the 2004 ASCUE Conference, Www.Ascue.Org, 39-49. https://files.eric.ed.gov/fulltext/ED490098.pdf

Covid19.go.id. (2020). Tanya Jawab Covid-19. https://covid19.go.id/tanyajawab?search=Apa yang dimaksud dengan pandemi

Dirani, K. M., \& Won Yoon, S. (2000). InternationalExploring Open Distance Learning at a Jordanian University: A Case Study. The International Review of Research in Open and Distributed Learning, 10(2), 125-133.

http://www.irrodl.org/index.php/irrodl/article/view/599/1251

Dumford, A. D., \& Miller, A. L. (2018). Online learning in higher education: exploring advantages and disadvantages for engagement. Journal of Computing in Higher Education, 30(3), 452-465. https://doi.org/10.1007/s12528-018-9179-z

Fojtík, R. (2018). Problems of Distance Education. International Journal of Information and Communication Technologies in Education, 7(1), 14-23. https://doi.org/10.2478/ijicte-2018-0002

Guri-Rosenblit, S. (2013). Distance Education Systems and Institutions in the Online Era: An Identity Crisis. https://doi.org/DOI: 10.1002/9781118557686.ch1

Heydenrych, J. F., \& Prinsloo, P. (2010). Revisiting the five generations of distance education : Quo vadis? Progressio, 32(1), 5-26.

Holmberg, B. (1989). Theory and Practice of Distance Education. Routledge.

Hrastinski, S. (2008). Asynchronous and Synchronous E-Learning. Educause Quartely, 4, 51-55. https://er.educause.edu/-/media/files/article-downloads/eqm0848.pdf

Huang, R., Tlili, A., Chang, T. W., Zhang, X., Nascimbeni, F., \& Burgos, D. (2020). Disrupted classes, undisrupted learning during COVID-19 outbreak in China: application of open educational practices and resources. Smart Learning Environments, 7(1). https://doi.org/10.1186/s40561-020-00125-8

Jung, I. (2019). Introduction to theories of open and distance learning. In Open and Distance Education Theory Revisited Implications for the Digital Era (pp. 1-9). Springer Nature.

Kebritchi, M., Lipschuetz, A., \& Santiague, L. (2017). Issues and Challenges for Teaching Successful Online Courses in Higher Education. Journal of Educational Technology Systems, 46(1), 4-29. https://doi.org/10.1177/0047239516661713

Keegan, D. (1983). Six distance education theorists. International Extension College.

Keegan, D. (1986). The foundations of distance education. Croom Helm.

King, F. B., Young, M. F., \& Richmond, K. (2001). Defining Distance Learning and Distance Education. In Educational Technology Review (Issue May 2014).

Kutluk, F. A., \& Gulmez, M. (2012). A Research about Distance Education Students' 
Satisfaction with Education Quality at an Accounting Program. Procedia - Social and Behavioral Sciences, 46, 2733-2737. https://doi.org/10.1016/j.sbspro.2012.05.556

Mapuva, J. (2009). Confronting challenges to e-learning in Higher Education Institutions. International Journal of Education and Development Using Information and Communication Technology, 5(3), 101-114.

Markova, T., Glazkova, I., \& Zaborova, E. (2017). Quality Issues of Online Distance Learning. Procedia - Social and Behavioral Sciences, 237(June 2016), 685-691. https://doi.org/10.1016/j.sbspro.2017.02.043

Martens, R., Bastiaens, T., \& Kirschner, P. A. (2007). New learning design in distance education: The impact on student perception and motivation. Distance Education, 28(1), 81-93. https://doi.org/10.1080/01587910701305327

Mathew, I. R., \& Iloanya, E. J. (2016). Open and Distance Learning: Benefits and Challenges of Technology Usage for Online Teaching and Learning in Africa. PanCommonwealth Forum 8 (PCF8). http://hdl.handle.net/11599/2661

Messo, I. N. (2014). Students' Perception on the Quality of Open and Distance Learning Programmes in Tanzania. Huria - Journal of the Open University of Tanzania, 18(1), 119-134.

Moodley, S. (2002). Inclusive Education: Challenges for Distance Learning, Policy and Practice. Patways 6 Conference 2002, February 2001.

Moore, M. G., \& Kearsley, G. (2011). Distance education: A systems view of online learning (3rd ed.). Wadsworth Cengage Learning.

Musingafi, M. C. C., Mapuranga, B., Chiwanza, K., \& Zebron, S. (2015). Challenges for open and distance learning (ODL) students: Experiences from students of the Zimbabwe Open University. Journal of Education and Practice, 6(18), 59-66.

Newby, T. J., Stepich, D. A., Lehman, J. D., \& Russell, J. D. (2000). Instruction technology for teaching and learning. Merrill.

Novak, J. D. (1998). Learning, creating, and using knowledge: Concept maps as facilitative tools in schools and corporations. Erlbaum.

Nsamba, A. N. (2016). Exploring the quality of students ' support services in distance learning environments in the subject University of South Africa supervisor : prof M E Makoe March 2016. UNISA PhD Thesis, March.

Nwankwo, A. A. (2015). Students' Learning Experiences and Perceptions of Online Course Content and Interactions. ProQuest Dissertations and Theses, 137. https://lopes.idm.oclc.org/login?url=http://search.proquest.com/docview/16516 11965 ?accountid=7374\%5Cnhttp://xs6th8dt4r.search. serialssolutions.com/?ctx_ ver=Z39.88-2004\&ctx_enc=info:ofi/enc:UTF-

8\&rfr_id=info:sid/ProQuest+Dissertations+\%26+Theses+Global\&rft 
O'Donoghue, J., Singh, G., \& Green, C. (2004). A comparison of the advantages and disadvantages of IT based education and the implication upon students. Interactive Educational Multimedia: IEM, 9(9), 63-76.

Oliveira, M. M. S. de, Penedo, A. S. T., \& Pereira, V. S. (2018). Distance education: advantages and disadvantages of the point of view of education and society. Dialogia, 29, 139-152. https://doi.org/10.5585/dialogia.n29.7661

Owusu-Boampong, A., \& Holmberg, C. (2015). Distance education in European higher education - THE POTENTIAL (Report 3 (of 3) of the IDEAL (Impact of Distance Education on Adult Learning) project.). https://static1.squarespace.com/static/5b99664675f9eea7a3ecee82/t/5c865570 08522903c3b034c2/1552307582370/ideal_report_3_extended.pdf

Pardanjac, M., Radosav, D., \& Jokic, S. (2009). Advantages and disadvantages of distance learning. MIPRO 2009 - 32nd International Convention Proceedings: Computers in Education, 4(381), 237-241. https://doi.org/10.23947/itno.2020.248-250

Perveen, A. (2016). Synchronous and Asynchronous E-Language Learning: A Case Study of Virtual University of Pakistan. Open Praxis, 8(1), 21-39. https://doi.org/10.5944/openpraxis.8.1.212

Peters, O. (2007). The most industrialized form of education. In M. G. Moore (Ed.), Handbook of distance education (2nd ed., pp. 57-68). Lawrence Erlbaum Associates.

Pishvanova, V., Malinko, E., \& Tsyganok, Z. (n.d.). Advantages And Disadvantages of Distance Learning. https://ir.kneu.edu.ua/bitstream/handle/2010/8423/609614.pdf?sequence $=1$

Pranita, E. (2020). Diumumkan Awal Maret, Ahli: Virus Corona Masuk Indonesia dari Januari. Kompas.Com. https://www.kompas.com/sains/read/2020/05/11/130600623/diumumkanawal-maret-ahli--virus-corona-masuk-indonesia-dari-januari

Ramírez Montoya, M. S. (2013). Retos y perspectivas en el movimiento educativo abierto de educación a distancia: Estudio diagnóstico en un proyecto SINED. RUSC Universities and Knowledge Society Journal, 10(2), 414-430. https://doi.org/10.7238/rusc.v10i2.1719

Rezaei, M. (2009). Challenges of developing online learning in higher education in Iran. Turkish Online Journal of Distance Education-TOJDE, 10(4), 80-90.

Schlosser, L. A., \& Simonson, M. R. (2009). Distance education: Definitions and glossary of terms (Second). Information Age Publishing.

Simonson, M., \& Schlosserharles, C. (1999). Theory and distance education : A new discussion. American Journal of Distance Education, 13(1), 60-75. 
https://doi.org/https://doi.org/10.1080/08923649909527014

Simonson, M., Smaldino, S., Albright, M., \& Zvacek, S. (2006). Teaching and learning at a distance: Foundations of distance education. Pearson.

Svinicki, M., \& McKeachie, W. J. (2011). Teaching tips: Strategies, research, and theory for college and university teachers (13th ed.). Wadsworth.

Tao, Y. H., \& Rosa Yeh, C. C. (2008). Typology of teacher perception toward distance education issues - A study of college information department teachers in Taiwan. Computers and Education, 50(1), 23-36. https://doi.org/10.1016/j.compedu.2006.03.005

Tibi, M., \& Tibi, L. (2009). Distance Learning: What are its Strengths and Pitfalls? Journal in Educational and Social Sciences, 13(2003), 71-98.

Trianto. (2007). Model-model pembelajaran inovatif berorientasi kontruktivistik. Prestasi Pustaka.

UNESCO. (2002). Open And Distance Learning: Trends, Policy And Strategy Considerations. In Education + Training. https://doi.org/10.1108/eb017294

Vlasenko, L., \& Bozhok, N. (2013). Advantages and Disadvantages of Distance Education. International Journal of Instructional Technology and Distance Learning, 10(10), 53-58.

Wang, H.-Y. (2015). Challenges for Distance Education: A cultural analytic perspective on asynchronous online courses in Sweden. https://lup.lub.lu.se/studentpapers/search/publication/5045707

Watson, J. (2008). Blended Learning: The Convergence of Online and Face-to-Face Education. https://files.eric.ed.gov/fulltext/ED509636.pdf

West, R., \& Turner, L. H. (2008). Pengantar teori komunikasi: Analisis dan aplikasi (3rd ed.). Penerbit Salemba Humanika.

Widyanuratikah, I. (2020, April 10). Hampir 100 Persen Perguruan Tinggi Terapkan PJJ. Republika. https://republika.co.id/berita/q8kyzq430/hampir-100-persenperguruan-tinggi-terapkan-pjj

Yaumi, M. (2007). the Implementation of Distance Learning in. Learning, 1996, 196215. 